\title{
Invasive alien plants of Russia: insights from regional inventories
}

\author{
Yulia Vinogradova · Jan Pergl $@$ - Franz Essl - Martin Hejda - Mark van Kleunen • \\ REGIONAL CONTRIBUTORS • Petr Pyšek (i)
}

\begin{abstract}
Recent research on plant invasions indicates that some parts of the world are understudied with temperate Asia among them. To contribute towards closing this gap, we provide a standardized list of invasive alien plant species with their distributions in 45 Russian regions, and relate the variation in their richness to climate, socioeconomic parameters and human influence. In total, we report 354 invasive alien species. There are, on average, $27 \pm 17$ (mean \pm SD) invasive plants per region, and the invasive species richness varies from zero in Karelia to 71 in Kaluga. In the European part of Russia, there are 277
\end{abstract}

\section{Y. Vinogradova}

Main Botanical Garden Named After N.V. Tsitsin,

Russian Academy of Sciences, Moscow, Russia 127276

J. Pergl $(\varangle) \cdot$ M. Hejda · P. Pyšek

Department of Invasion Ecology, Institute of Botany, The Czech Academy of Sciences, 25243 Průhonice, Czech Republic

e-mail: pergl@ibot.cas.cz

\section{F. Essl}

Division of Conservation, Vegetation and Landscape Ecology, University of Vienna, Rennweg 14, 1030 Vienna, Austria invasive species in total, in Siberia 70, and in the Far East 79. The most widespread invaders are, in terms of the number of regions from which they are reported, Acer negundo, Echinocystis lobata (recorded in 34 regions), Erigeron canadensis and Elodea canadensis (recorded in 30 regions). Most invasive species in Russia originate from other parts of temperate Asia and Europe. There were significant differences in the representation of life forms between the European, Siberian and Far East biogeographical regions, with perennials being over-represented in the Far East, and shrubs in the European part of Russia. The richness of invasive species can be explained by climatic factors, human population density and the percentage of urban population in a region. This publication and the associated dataset is the first comprehensive treatment of the invasive flora of Russia using standardized

\footnotetext{
M. van Kleunen

Zhejiang Provincial Key Laboratory of Plant Evolutionary Ecology and Conservation, Taizhou University, Taizhou 318000, China

M. van Kleunen

Ecology, Department of Biology, University of Konstanz, Universitätsstrasse 10, 78467 Konstanz, Germany

P. Pyšek

Department of Ecology, Faculty of Science, Charles University, Viničná 7, 12844 Prague, Czech Republic
} 
criteria and covering $83 \%$ of the territory of this country.

Keywords Climate - Exotic plants - Invasive flora Life-form $\cdot$ Russia $\cdot$ Socioeconomic factors

\section{Introduction}

In recent years there has been considerable progress in developing regional inventories of alien plant species (see Pyšek et al. 2017 for an overview). Such inventories represent key inputs for continental and global databases (Lambdon et al. 2008; van Kleunen et al. 2015) that provide data for testing general hypotheses on biological invasions (e.g. Dellinger et al. 2016; Maurel et al. 2016; Razanajatovo et al. 2016; Dawson et al. 2017), identifying long-term trends in species introductions (Seebens et al. 2017) as well as drivers associated with invasions (Pyšek et al. 2015; Seebens et al. 2015; Dawson et al. 2017). As there are clearly documented impacts of alien plants on the environment and human livelihoods by a subset of alien species (Vilà et al. 2010, 2015; Pyšek et al. 2012; Kumschick et al. 2015; Rumlerová et al. 2016), biological invasions have become a focus of national (Essl et al. 2011; Pergl et al. 2016b) and international policies (Hulme et al. 2009; Genovesi et al. 2015; Pergl et al. 2016a).

Comprehensive and rather complete lists of naturalized alien plants in regions (countries, islands, federal states or provinces of large countries) using a standardized classification of invasion status, mostly following the one proposed by Richardson et al. (2000), started to appear in the 2000s. For example, in Europe, the first national alien plant species checklists were published in 2002 for Austria (Essl and Rabitsch 2002) and the Czech Republic (Pyšek et al. 2002). The European Union-funded DAISIE project (DAISIE 2009) led to the compilation and update of alien plant species inventories for many countries in this continent (e.g. Medvecká et al. 2012; Pyšek et al. 2012). Similar activities were also done e.g. in temperate Asia, and elsewhere (e.g. Liu et al. 2006; Wu et al. 2010; Jiang et al. 2011; Xu et al. 2012; Shrestha 2016; Uludag et al. 2017; Inderjit et al. 2018). However, despite this substantial progress, recent publications that provide the most comprehensive overviews of naturalized plant species inventories worldwide (van Kleunen et al. 2015; Pyšek et al. 2017) show that there are still some major data gaps in global coverage, the biggest one being large parts of temperate Asia (see van Kleunen et al. 2015, their Fig. 1). Global knowledge of the distribution of invasive plants, i.e. the subset of naturalized plants that rapidly spread over large distances from focal populations (Richardson et al. 2000; Blackburn et al. 2011), is even more limited than is the case with naturalized plants and up to date information on numbers of invasive plant species in world regions has only been summarized recently (Pyšek et al. 2017).

Improving the knowledge of distributions and richness of alien plant species, both naturalized and invasive, in poorly studied regions is important for many reasons including better understanding of factors determining local invasions, but also for obtaining a more complete picture of global alien species richness (Pyšek et al. 2008, 2017; van Kleunen et al. 2015). Only thoroughly compiled inventories that aim at obtaining complete lists of alien species for individual regions, provide a robust basis for analyses of regional levels of invasions and underlying drivers (Pyšek et al. 2018). Even if such inventories do not record all alien species, specifically casuals or less widely distributed naturalized species that are difficult to capture in countries with a poorer tradition of floristic research, it is important to aim at completeness for the category chosen for the study, be it naturalized or invasive species (Latombe et al. 2017).

With regard to coverage of administrative regions, the largest current gap refers to Russia. The European region of Russia has largely been accounted for in the GloNAF database of the world's naturalized floras (see van Kleunen et al. 2015; Pyšek et al. 2017 for details), as were some regions in the Far East. However, data from the Asian region of Russia is largely missing. The floristic information is mostly scattered in grey literature (Grigorevskaya et al. 2004; Borisova 2007; Morozova et al. 2008; Krylov and Reshetnikova 2009; Khorun et al. 2012) and primarily published in the Russian language. The comparability of the lists often suffers from the lack of standardized terminology and some data sources focus only on subsets of naturalized plants such as those that are considered to cause negative impacts on the environment or human livelihoods (such as Black Books: Vinogradova et al. 2010, 2011; Vinogradova and 
Kuprianov 2016). Indeed, despite numerous local papers and reports on the presence of alien plant species in different subregions of Russia (Mayorov et al. 2012; Rzhevuskaya 2012; Tremasova et al. 2012; Antonova 2013; Panasenko 2013; Silaeva and Ageeva 2016), no summarizing inventory of invasive species in individual regions of this country has been compiled so far. In this paper we aim at closing this gap for a large part of Russia. Given the vast size of the country and the variation in environmental conditions and human impacts, these data provide an excellent opportunity to explore the effects of natural and human-related factors on the regional levels of plant invasions in an important but understudied part of the globe.

We provide, for the first time based on standardized inventories of invasive plant species covering over $80 \%$ of its territory, (1) an account of plant invasions in Russia, and (2) we explore the basic taxonomic, biogeographic and ecological characteristics of its invasive flora. We also elucidate (3) the differences between the invasive species composition in different biogeographic regions of Russia, and (4) analyse the importance of environmental and socioeconomic drivers on the variation in regional invasive plant species richness.

\section{Methods}

Lists of invasive plant species and their attributes

To compile the inventories of invasive alien plant species for regions in Russia (Table 1), local experts for alien plants (see Electronic Appendix 1 for a list of regional contributors) were asked to provide lists of invasive alien species for the following groups: (1) transformers sensu Richardson et al. (2000), defined as invasive species with impact on ecosystem functioning and (2) alien species becoming naturalized and rapidly spreading. These two categories correspond to the definition of invasive species, widely accepted in the current literature (following the criteria of Richardson et al. 2000; Pyšek et al. 2004; Blackburn et al. 2011). The regional contributors coordinated the compilation of the lists of invasive species for their regions on the basis of data provided by local botanists, working in defined small districts, by using the same guidelines (Notov et al. 2011). These lists were based on field knowledge, literature, herbarium and unpublished records. We considered also aliens of Russian origin, i.e. species that are native in a part of Russia but alien to another part (similar as aliens in and to Europe in Lambdon et al. 2008).

Data on life form and geographic origin of the species were extracted from the working database GloNAF (van Kleunen et al. 2015; Pyšek et al. 2017) and verified by inspecting local floras and other sources. To link the list obtained to the GloNAF database, the taxonomy of "The Plant List" (version 1.1; http://www.theplantlist.org) was used to standardize the original names (i.e. synonyms were replaced by accepted scientific names; see van Kleunen et al. 2015) using the $\mathrm{R}$ package Taxonstand (Cayuela et al. 2017). As to life form, species were classified into the following categories: annual herb, perennial herb (including biennials, to group species that survive winter in other form than seed), shrub, tree, climber, and aquatic plants. To classify the region of origin, each species was assigned to one or more of the major biogeographically defined areas (continents) of the Taxonomic Databases Working Group (Brummit 2001). Species whose native range is unknown as they are only known from cultivation and species that originated through recent human-mediated hybridization are listed as a separate category. Data on the origin of species were primarily extracted from GRIN (https://npgsweb.ars-grin.gov) and then checked by literature and web searches (e.g. www. botany.cz, www.plants.jstor.org, www.issg.org).

Study region

Forty-five regions were covered by our survey (Table 1) accounting for $83 \%$ of the territory of Russia. Twenty-eight regions belong to the European part of Russia (accounting for 14\% of the Russian territory), 12 to Siberia (59\%) and two to the Far East (10\%) (Fig. 1).

The climatic conditions of Russia vary widely along the north-south gradient as well as from west to east. To characterize the climate in individual regions, we used 19 bioclimatic variables available through the WorldClim database (Hijmans et al. 2005). We performed a principal component analysis (PCA) with the first three axes explaining nearly $85 \%$ of the variation present in the original 19 variables (Dupin et al. 2011). The resulting PCA axes represent three uncorrelated linear 
Table 1 The numbers of invasive species and geographic characteristics of the 45 Russian regions used in this study
Biogeographic region: eur European part, sib Siberia, feast Far east

\begin{tabular}{|c|c|c|c|}
\hline Region & No. of invasive species & Biog. region & Area $\left(\mathrm{km}^{2}\right)$ \\
\hline Adygey & 23 & eur & 8136 \\
\hline Aga Buryat & 4 & sib & 563,974 \\
\hline Altay & 25 & sib & 184,258 \\
\hline Astrakhan' & 18 & eur & 46,932 \\
\hline Bashkortostan & 29 & eur & 145,883 \\
\hline Belgorod & 62 & eur & 28,374 \\
\hline Bryansk & 26 & eur & 34,382 \\
\hline Buryat & 5 & sib & 443,570 \\
\hline Evenk & 21 & sib & 851,364 \\
\hline Gorno-Altay & 13 & sib & 105,467 \\
\hline Irkutsk & 19 & sib & 923,495 \\
\hline Ivanovo & 42 & eur & 23,712 \\
\hline Kaliningrad & 31 & eur & 13,758 \\
\hline Kaluga & 71 & eur & 29,114 \\
\hline Karelia & 0 & eur & 175,821 \\
\hline Kemerovo & 16 & sib & 106,119 \\
\hline Khabarovsk & 41 & feast & $1,139,345$ \\
\hline Khakass & 14 & sib & 67,599 \\
\hline Komi & 8 & eur & 418,782 \\
\hline Kostroma & 24 & eur & 60,285 \\
\hline Krasnodar & 49 & eur & 77,244 \\
\hline Leningrad & 20 & eur & 144,952 \\
\hline Maga Buryatdan & 41 & feast & 647,038 \\
\hline Mordovia & 29 & eur & 26,212 \\
\hline Moscow & 37 & eur & 47,999 \\
\hline Murmansk & 4 & eur & 143,621 \\
\hline Nizhegorod & 56 & eur & 74,930 \\
\hline North Ossetia & 22 & eur & 7255 \\
\hline Novosibirsk & 13 & sib & 190,094 \\
\hline Omsk & 16 & sib & 146,123 \\
\hline Pskov & 33 & eur & 56,962 \\
\hline Sakha & 3 & sib & $3,819,822$ \\
\hline Samara & 30 & eur & 53,593 \\
\hline Saratov & 44 & eur & 101,093 \\
\hline Sverdlovsk & 61 & eur & 196,532 \\
\hline Tomsk & 15 & sib & 337,399 \\
\hline Tula & 30 & eur & 25,503 \\
\hline Tuva & 1 & sib & 19,7918 \\
\hline Tver' & 34 & eur & 85,533 \\
\hline Udmurt & 45 & eur & 41,729 \\
\hline Ul'yanovsk & 23 & eur & 36,887 \\
\hline Vladimir & 33 & eur & 29,128 \\
\hline Volgograd & 28 & eur & 260,453 \\
\hline Voronezh & 29 & eur & 51,721 \\
\hline Yaroslavl' & 40 & eur & 35,939 \\
\hline
\end{tabular}


Fig. 1 Map of the study area with indication of the numbers of invasive plant species in the Russian regions, with location in the European, Siberian and Far East parts of the territory indicated. Grey areas indicate the absence of data on invasive species
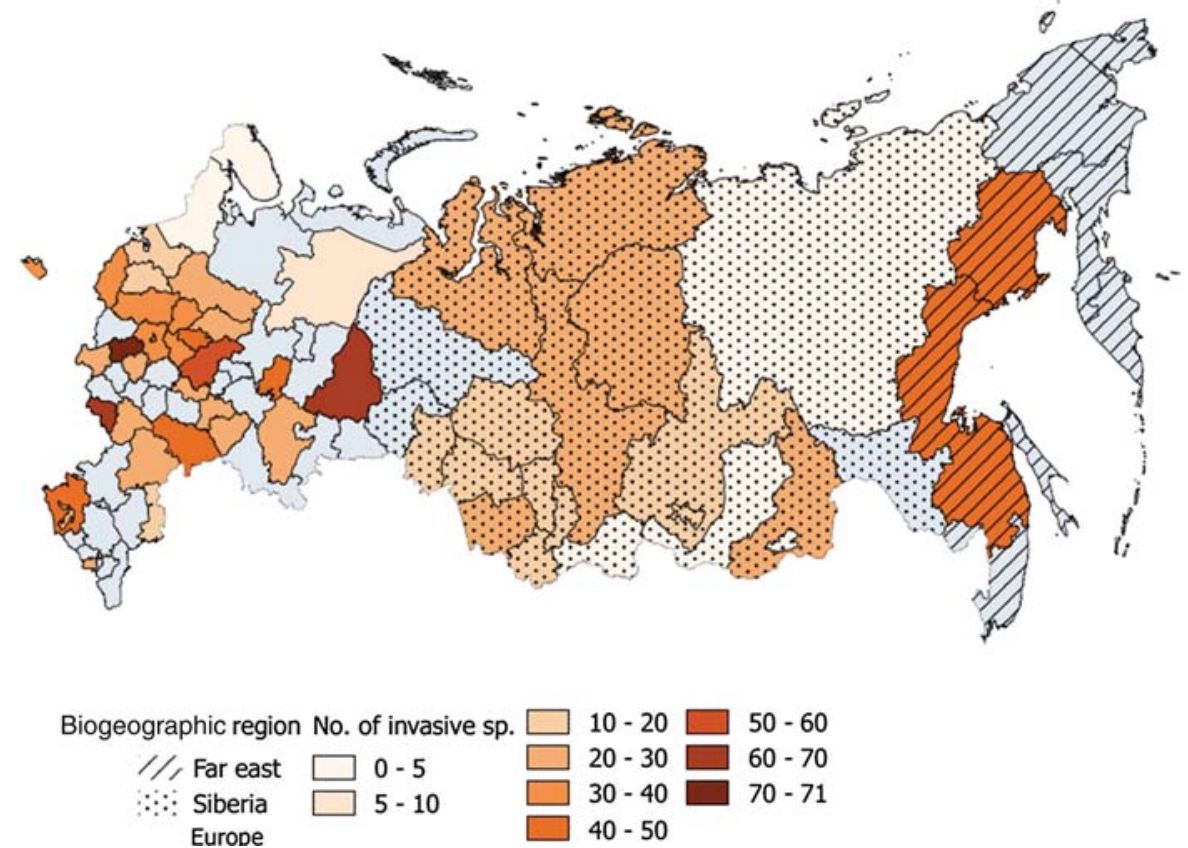

combinations of the original data, with the first one (PCA score 1) related mainly to mean annual temperature, the second (PCA score 2) mainly to precipitation during wet or warm periods, and the third (PCA score 3) to precipitation during dry seasons.

In addition to climate, we collated data on factors related to land use and human pressure for each region. The following characteristics of land use were obtained: proportion of agricultural land (Federal State Statistics Service 2015), and the average size of roadless areas (i.e. patches) within the region (http://roadless.online; Ibisch et al. 2017). Other proxies related to propagule pressure and land use were human population density and the proportion of the population living in urban areas (Federal State Statistics Service 2015).

As data on invasive species were collected on a regional scale while data on the above factors were sometimes available at a finer grain of subregions, the latter were summed (e.g. human population from several subregions within a region, or subregions' areas) or averaged (climate factors, size of roadless areas).

\section{Statistical analysis}

Two approaches were used to analyse the geographical and life-form patterns in the invasive flora of
Russia. To test whether there are differences in the numbers of invasive species among regions in Europe, Siberia and the Far East, in terms of representation of species with different life forms and of different origin, their counts were analysed by row $\times$ column contingency tables, using generalized linear models (GLMs) with the log-link function and a Poisson distribution of errors (e.g. Crawley 2007). For the models that significantly explained the effects, adjusted standardized residuals of G-tests were then compared with critical values of the normal distribution to ascertain for which species groups the counts

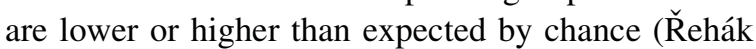
and Řeháková 1986).

To test the effect of environmental and socioeconomic variables (climate PCA scores, human population density, percentage of urban population, proportion of agricultural land and roadless area) on the number of invasive species in individual regions, regression trees were applied (Breiman et al. 1984; De'ath and Fabricius 2000). To account for variation in size of the regions, the area of each region was taken as a weighing factor. Regression trees were constructed using binary recursive partitioning, with the default Gini index impurity measure used as the splitting index, in CART v. 7.0 (Breiman et al. 1984; Steinberg and Colla 1995). To find an optimal tree, a 
sequence of nested trees of decreasing size, each being the best of all trees of its size, was produced, and their resubstitution relative errors, corresponding to residual sums of squares, were estimated. Ten-fold crossvalidation was used to obtain estimates of crossvalidated relative errors for these trees.

Clustering (Ward method) (Crawley 2007) was used for visualizing the patterns in differences between the regions according to the species composition. The calculations were done in $\mathrm{R}$ 3.0.2 ( $\mathrm{R}$ Development Core Team 2017).

\section{Results}

Invasive alien species in Russian regions

The invasive alien flora of the 45 Russian regions included in this study consists of 354 species (see Electronic Appendix S2 for the complete list of species and their distribution in the regions). The invasive species richness varied across the regions (Table 1, Fig. 1), ranging from zero in Karelia to 71 in Kaluga (both these regions are in the European part). In the European part of Russia, there are 277 invasive species in total, in Siberia 70 and in the Far East 79. The average number of invasive species per region in Russia is $27 \pm 17$ (mean $\pm \mathrm{SD}$; median $=26$ ). The most widespread species are Acer negundo and Echinocystis lobata (recorded in 34 regions) followed by Erigeron canadensis and Elodea canadensis (30 regions). The vast majority of species has a very limited distribution; 228 of the 354 species were recorded in only one region (Fig. 2).

Cluster analysis (Ward method; Fig. 3) based on the invasive alien species lists in regions reflected the biogeographical position of regions, placing the majority of European ones in a separate cluster that is most distant from the two Far East regions. The Siberian regions formed a separate cluster that includes some European regions that border Siberia.

Taxonomic composition, origin and life forms

The 354 species belong to 65 families and 221 genera. The greatest numbers of invasive species are found in Compositae (62 species), Poaceae (40) and Rosaceae (35) (Table 2), while 25 families are represented by only one species. The genera richest in invasive species are Prunus (9), Bromus (6), Salix (6), Atriplex (5) and Lepidium (5), while 37 genera are represented by two species and 144 by one species.

Using the Biodiversity Information Standards (TDWG) delineation of continents, most invasive species originate from temperate Asia (274 species) and Europe (241). In terms of proportional contribution to the total invasive flora, $78 \%$ of the species have their native range in temperate Asia, 68\% in Europe, $31 \%$ in North America, 31\% in Africa and 29\% in tropical Asia. Despite a trend for a higher proportion of plants originating from North America and tropical Asia in the Far East, the differences among the European, Siberian and Far East regions were not significant $\left(\chi^{2}=4.45, d f=10, p=0.92\right)$. Among the top 10 species recorded in the Russian regions, eight have native ranges in North America.

The invasive flora of Russia consists of $41 \%$ perennial herbs (203 species), 28\% annuals (138), $15 \%$ shrubs (77), $11 \%$ trees (57), $5 \%$ climbers (24) and $1.4 \%$ (4) aquatic species. There were significant differences in the representation of life forms among the biogeographical regions $\left(\chi^{2}=29.78, d f=10\right.$; $p<0.001$; Fig. 4). Perennials were marginally $(p<0.1)$ significantly over-represented in the Far East, and shrubs in the European part of Russia. Highly significantly $(p<0.01)$ under-represented were shrubs and trees in the Far East (Fig. 4).

Factors associated with regionally high numbers of invasive species

The regression tree revealed that climatic factors (average annual temperature and precipitation during the dry season), human population density and the percentage of urban population are highly important factors for shaping the richness of invasive alien flora in a Russian region (Fig. 5). There were also other factors contributing to the patterns of regional invasive species richness, as indicated by surrogates that were closely associated with the primary splitting variables: the percentage of population living in a region that is urban, and the extent of roadless area.

The three regions with PCA axis 3 scores lower than -0.79 (regions with very little precipitation in the dry season) harbour the lowest numbers of invasive species, i.e. only three on average. The surrogates for this split were the percentage of urban population, population density and PCA axis 1 . Regions with a 
Fig. 2 Frequency

distribution of invasive plant species in Russian regions $(\mathrm{n}=45)$

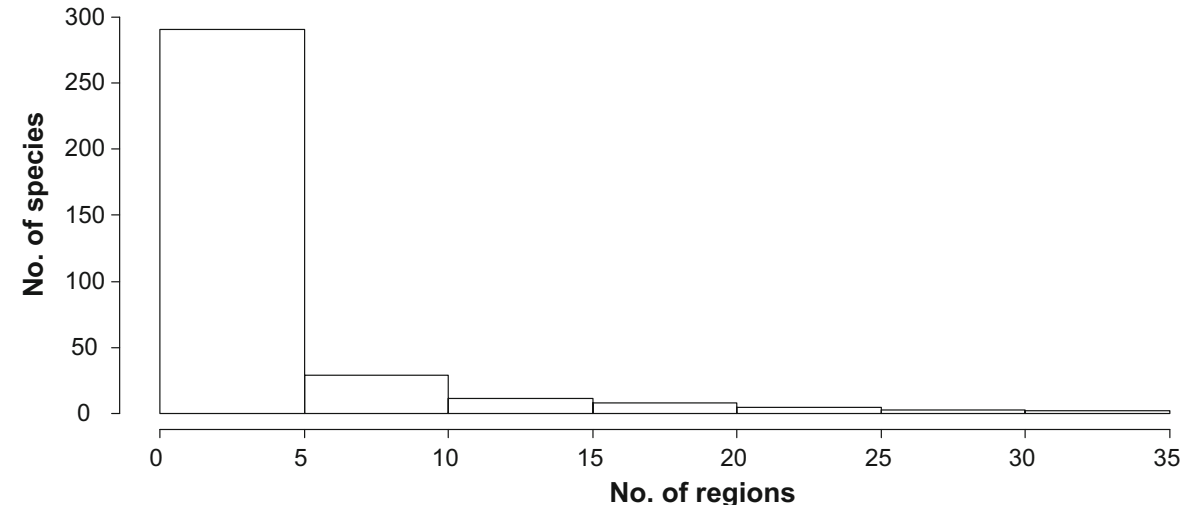

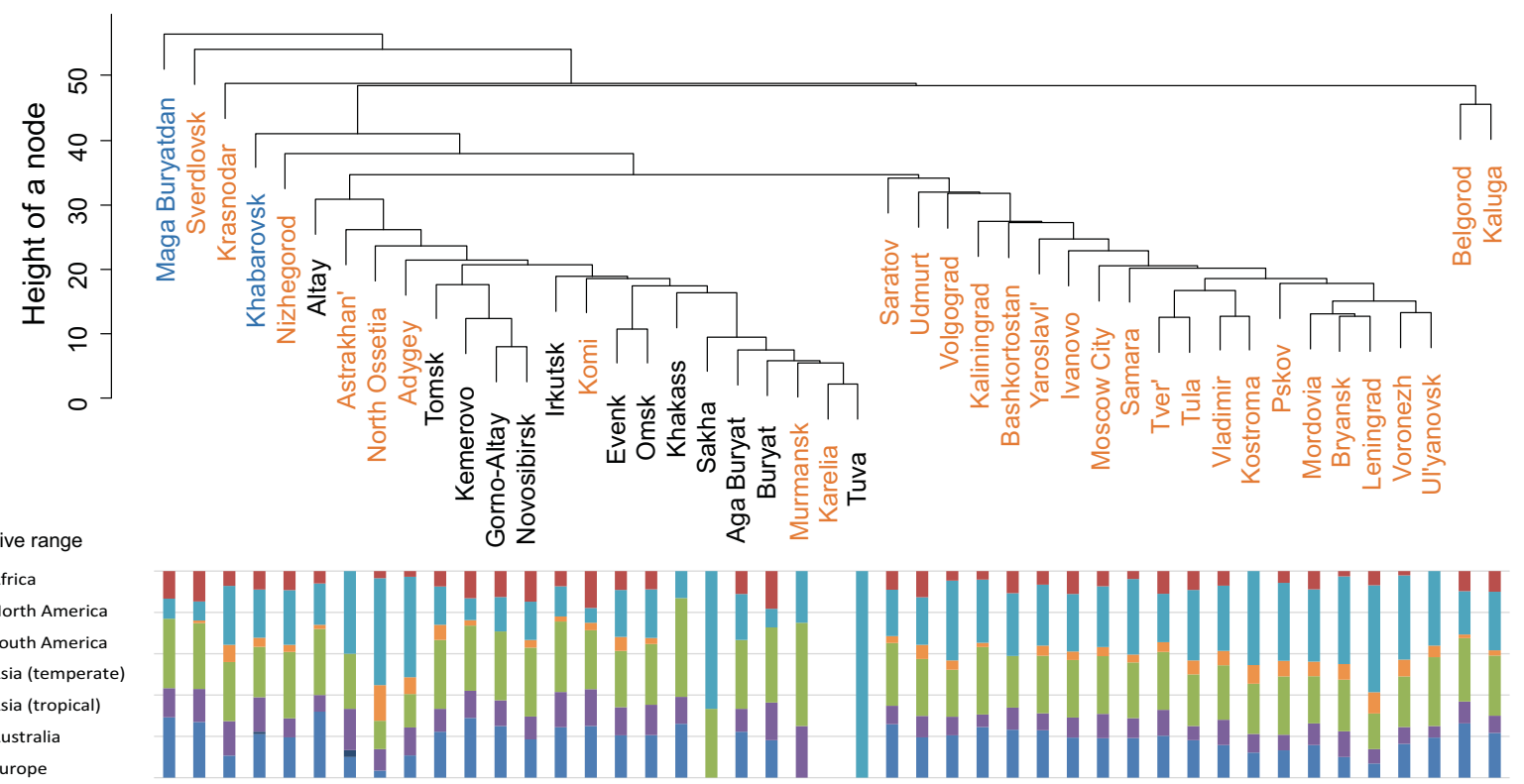

Fig. 3 Cluster tree (Ward method) showing the similarity of regions based on the invasive species composition. Regions marked by red are from the European part of Russia, black from

Siberia and blue from Far East. Below the tree is shown a bar graph visualizing the proportions of origins

score above -0.79 on PCA axis 3 are richest in invasive species if, at the same time, the score on PCA axis 1 , reflecting mean annual temperature, is lower than -1.26 . Regions with low human population density harbour few invasive aliens, especially if there is a large extent of roadless area (Fig. 5).

\section{Discussion}

Our research yielded a dataset of 354 alien plant species that have become invasive in at least one of the 45 Russian regions for which we had data. Given that we covered more than $80 \%$ of the territory of Russia, this number is conservative and the total number of invasive plant species in Russia is likely to be higher. Nevertheless, the value of the dataset is that it is the first comprehensive treatment of the invasive flora of Russia using a standardized terminology (Richardson et al. 2000; Blackburn et al. 2011). This is important because up to now, many papers in the Russian literature on alien species (Lysenko 2010; Fomina and Tokhtar 2012) were using traditional Central-European terminology stemming from the approach of Thellung (1912) and his followers (e.g. Holub and Jirásek 1967; Schroeder 1969; see Kowarik and Pyšek 
Table 2 The most represented species in the invasive flora of Russia, with information on the number of regions where they occur, continent of origin and life form

\begin{tabular}{|c|c|c|c|c|}
\hline Species & Family & $\begin{array}{l}\text { No. of } \\
\text { regions }\end{array}$ & Continent of origin & Life-form \\
\hline Acer negundo & Sapindaceae & 34 & $\mathrm{~N}$ America & Tree \\
\hline Echinocystis lobata & Cucurbitaceae & 34 & $\mathrm{~N}$ America & Annual \\
\hline Erigeron canadensis & Compositae & 30 & N America & Annual \\
\hline Elodea canadensis & Hydrocharitaceae & 30 & $\mathrm{~N}$ America & Perennial herb \\
\hline Bidens frondosa & Compositae & 24 & $\mathrm{~N}$ America & Annual \\
\hline Epilobium ciliatum & Onagraceae & 23 & N \& S America, Asia temperate & Perennial herb \\
\hline Impatiens glandulifera & Balsaminaceae & 23 & Asia tropical & Annual \\
\hline Heracleum sosnowskyi & Apiaceae & 21 & Asia temperate & Perennial herb \\
\hline Juncus tenuis & Juncaceae & 21 & $\mathrm{~N} \& \mathrm{~S}$ America & Perennial herb \\
\hline Solidago canadensis & Compositae & 20 & $\mathrm{~N}$ America & Perennial herb \\
\hline Impatiens parviflora & Balsaminaceae & 19 & Asia temperate & Annual \\
\hline Amelanchier spicata & Rosaceae & 18 & $\mathrm{~N}$ America & Shrub \\
\hline Sambucus racemosa & Adoxaceae & 18 & $\mathrm{~N}$ America & Shrub, tree \\
\hline Erigeron annuus & Compositae & 17 & $\mathrm{~N}$ America & Annual \\
\hline Lupinus polyphyllus & Leguminosae & 17 & $\mathrm{~N}$ America & Perennial herb \\
\hline Oenothera biennis & Onagraceae & 17 & $\mathrm{~N}$ America & Perennial herb \\
\hline Helianthus tuberosus & Compositae & 16 & $\mathrm{~N}$ America & Perennial herb \\
\hline Elaeagnus rhamnoides & Elaeagnaceae & 16 & Asia temperate \& tropical, Europe & Shrub, tree \\
\hline Amaranthus retroflexus & Amaranthaceae & 14 & $\mathrm{~N}$ America & Annual \\
\hline Lepidium densiflorum & Brassicaceae & 14 & N America & $\begin{array}{l}\text { Annual, perennial } \\
\text { herb }\end{array}$ \\
\hline Matricaria discoidea & Compositae & 14 & Asia temperate & Annual \\
\hline Epilobium pseudorubescens & Onagraceae & 13 & Asia temperate, Europe & Perennial herb \\
\hline Fraxinus pennsylvanica & Oleaceae & 13 & $\mathrm{~N}$ America & Tree \\
\hline Hordeum jubatum & Poaceae & 13 & Asia temperate & Perennial herb \\
\hline Symphyotrichum salignum & Compositae & 13 & hybrid & Perennial herb \\
\hline Xanthium albinum & Compositae & 13 & $\mathrm{~N}$ America & Annual \\
\hline Acorus calamus & Acoraceae & 12 & Asia temperate \& tropical & Perennial herb \\
\hline Parthenocissus inserta & Vitaceae & 12 & N America & Climber \\
\hline Solidago gigantea & Compositae & 12 & $\mathrm{~N}$ America & Perennial herb \\
\hline Aronia mitschurinii & Rosaceae & 11 & Hybrid & Shrub \\
\hline Oenothera rubricaulis & Onagraceae & 11 & N America & Perennial herb \\
\hline Echinochloa crus-galli & Poaceae & 10 & $\begin{array}{l}\text { Africa, Asia temperate \& tropical, } \\
\text { Europe }\end{array}$ & Annual \\
\hline Saponaria officinalis & Caryophyllaceae & 10 & Asia temperate & Perennial herb \\
\hline Ulmus pumila & Ulmaceae & 10 & Asia temperate & Shrub, tree \\
\hline
\end{tabular}

2012 for review; Pyšek et al. 2002 for comparison of terminologies). Another important feature of the present inventory is that it reflects the up-to-date current knowledge of invasive plants in individual regions because the team of authors include local experts who provided data and have the best knowledge of their territories. This makes the present dataset somewhat different from inventories that rely solely on literature sources and may therefore be in some cases outdated. 
Fig. 4 Frequency distribution of life forms in the three biogeographical areas. Regions that significantly differ among the two groups (G-test, $p$ ** $<0.01, .<0.1)$ are marked by an arrow, with its direction indicating over- or the group under-representation within
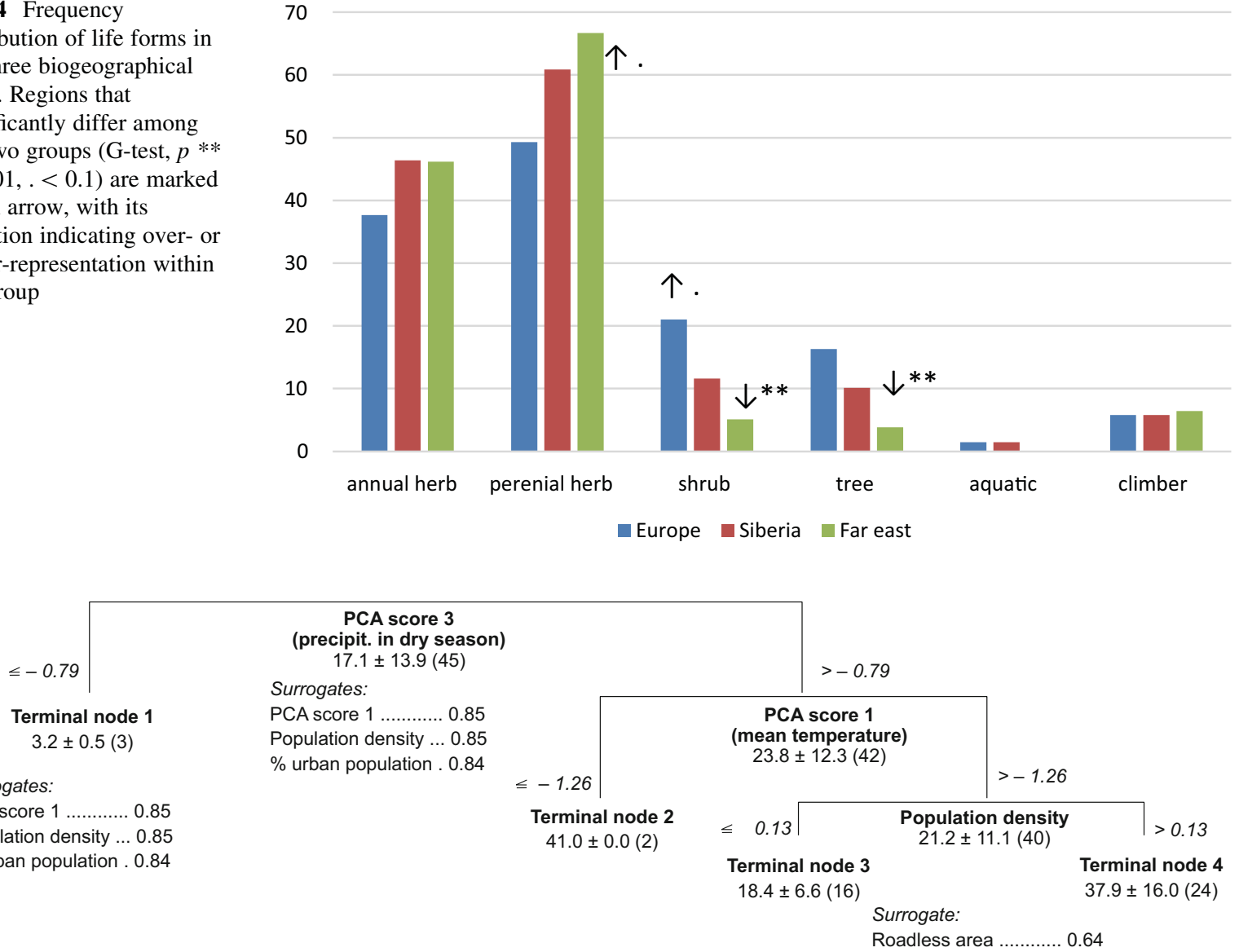

Fig. 5 Regression tree with the number of invasive plant species in a region as the explained variable. Each splitting node (splitting variable name and splitting criterion) and each terminal node show the number (mean $\pm \mathrm{SD}$; number of cases)

Our study, which combines data from several biogeographical regions, provides a reasonably robust picture of the most successful invasive alien plant species in Russia. Overall, we identified eight species that are present in at least half of the regions (Acer negundo, Echinocystis lobata, Erigeron canadensis, Elodea canadensis, Oenothera biennis, Bidens frondosa, Epilobium adenocaulon and Impatiens glandulifera). Interestingly, the four most widespread species belong to the families Sapindaceae, Cucurbitaceae, Compositae and Hydrocharitaceae, but the families with the largest numbers of invasive species are different, with the only exception of Compositae. Besides the Compositae family, which is richest in invasive species (62) and was shown in other studies to contain high numbers of alien plant species (Pyšek of invasive species weighted by the area of the region. Surrogates are shown in cases where the association value is above 0.6

1997, 1998; Daehler 1998; Pyšek et al. 2017), Poaceae (40 species) and Rosaceae (35 species) contribute most species to the invasive alien flora. This pattern is in accordance with many previous studies that explored the taxonomic structure of alien floras in the temperate zone (e.g. Lambdon et al. 2008; Pyšek et al. 2017), and might reflect that these families are among the largest ones globally.

Overall, the prevailing life forms in the Russian invasive flora are annual and perennial herbs, which account for $39 \%$ and $57 \%$ of the species, respectively. Shrubs (22\%) and trees (16\%) are less represented. However, there are differences in the representation of life forms among the broad biogeographical zones, with the invasive flora of the Far East having a significantly higher percentage of perennial herbs 
compared to shrubs and trees. We argue that this pattern is likely to be related to the particularly harsh climatic conditions in the Far East that are unfavourable for establishment and growth of woody species. This hypothesis seems to be supported by the fact that the two Far East regions are floristically somewhat distinct from other parts of Russia. Compared to the other parts of Russia, the Far East is characterized by tall herbaceous vegetation.

The highest numbers of invasive species were found in the Moscow region as might be expected due to intense human influence there. The overall pattern of invasive species richness is driven by the interaction of climate and socioeconomic factors reflecting human pressures such as the extent of roadless areas and the proportion of urban population. Human population density is a key factor positively correlated with invasive species richness, confirming the results of previous studies performed for Europe (Pyšek et al. 2010), and all other socioeconomic factors appear in our analyses only as statistical surrogates (Fig. 5). With regard to climate, results of our analyses show, that temperature is important but not the most important constraint to invasive plants in Russia; the first split in the regression tree indicates the significant role of the intra-annual distribution of precipitation in Siberia. Likewise, the two Far East regions, where the mean annual temperatures are particularly low, harbour rather rich invasive floras. One possible factor that is specific to these regions and could be partly responsible for an increased invasive species richness is the presence of ports, as coastal areas have been shown to act, in general, as invasion hotspots (Xu et al. 2012; Dawson et al. 2017). The expectations that harsh climatic conditions and low human population density act against the presence of invasive species, as found in the majority of the regions of Siberia, were confirmed by lower richness of invasive plant species than in European regions.

We conclude that despite the wide range of environmental and historical conditions, the invasive flora of Russia within each of the European, Siberian and Far East parts is rather homogeneous. This can be a result of synchrony between the historical development and limited trade within neighbouring regions and with other continents, but this situation may change rapidly in the future with changing climate and increasing trade (see e.g. Seebens et al. 2015). Such future trends might be best assessed by including data on complete alien floras, including all naturalized and casual species that are unfortunately not available at the moment.

Acknowledgements PP and JP were supported by Project No. 14-36079G Centre of Excellence PLADIAS (Czech Science Foundation) and long-term research development project RVO 67985939 (The Czech Academy of Sciences). PP acknowledges the support from Praemium Academiae award from The Czech Academy of Sciences. We thank Zuzana Sixtová, Martin Adámek and Matěj Man for technical assistance. MvK acknowledges support from the German Science Foundation (DFG; 264740629). FE was supported by the Austrian Science Foundation FWF (Grant I2086-B16).

\section{References}

Antonova LA (2013) Invasive component of flora in Khabarovsk krai. Russ J Biol Invas 4:69-73. https://doi.org/10. 1134/S2075111713020021

Blackburn TM, Pyšek P, Bacher S, Carlton JT, Duncan RP, Jarošík V, Wilson JRU, Richardson DM (2011) A proposed unified framework for biological invasions. Trends Ecol Evol 26:333-339. https://doi.org/10.1016/j.tree.2011.03. 023

Borisova EA (2007) Adventivnaya flora Ivanovskoi oblasti [Adventive flora of Ivanovo Oblast]. Ivanovskii Gosudarstvennyi Universitet, Ivanovo

Breiman L, Friedman JH, Olshen RA, Stone CG (1984) Classification and regression trees. Wadsworth International Group, Belmont

Brummit RK (2001) World geographical scheme for recording plant distributions, 2nd edn. Hunt Institute for Botanical Documentation, Pittsburgh

Cayuela L, Stein A, Oksanen J (2017) Taxonstand: taxonomic standardization of plant species names. $\mathrm{R}$ package version 2.0. R Foundation for Statistical Computing. https:// CRAN.R-project.org/package=Taxonstand

Crawley MJ (2007) The R book. Wiley, Chichester

Daehler C (1998) The taxonomic distribution of invasive angiosperm plants: ecological insights and comparison to agricultural weeds. Biol Conserv 84:167-180. https://doi. org/10.1016/S0006-3207(97)00096-7

DAISIE (2009) Handbook of alien species in Europe. Springer, Berlin

Dawson W, Moser D, van Kleunen M, Kreft H, Pergl J, Pyšek P, Weigelt P, Winter M, Lenzner B, Blackburn TM, Dyer E, Cassey P, Scrivens SL, Economo EP, Guénard B, Capinha C, Seebens H, García-Díaz P, Nentwig W, García-Berthou E, Casal C, Mandrak NE, Fuller P, Meyer C, Essl F (2017) Global hotspots of alien species across taxonomic groups. Nat Ecol Evol 1:0186. https://doi.org/10.1038/s41559017-0186

De'ath G, Fabricius KE (2000) Classification and regression trees: a powerful yet simple technique for ecological data analysis. Ecology 81:3178-3192. https://doi.org/10.1890/ 0012-9658(2000)081[3178:CARTAP]2.0.CO;2 
Dellinger AS, Essl F, Hojsgaard D, Kirchheimer B, Klatt S, Dawson W, Pergl J, Pyšek P, van Kleunen M, Weber E, Winter M, Hörandl E, Dullinger S (2016) Niche dynamics of alien species do not differ among sexual and apomictic flowering plants. New Phytol 209:1313-1323. https://doi. org/10.1111/nph.13694

Dupin M, Reynaud P, Jarošík V, Baker R, Brunel S, Eyre D, Pergl J, Makowski D (2011) Effects of the training dataset characteristics on the performance of nine species distribution models: application to Diabrotica virgifera virgifera. PLoS ONE 6:e20957. https://doi.org/10.1371/ journal.pone.0020957

Essl F, Rabitsch W (eds) (2002) Neobiota in Österreich. Umweltbundesamt GmbH, Wien

Essl F, Dullinger S, Rabitsch W, Hulme PE, Hülber K, Jarošík V, Kleinbauer I, Krausmann F, Kühn I, Nentwig W, Vilà M, Genovesi P, Gherardi F, Desprez-Lousteau M-L, Roques A, Pyšek P (2011) Socioeconomic legacy yields an invasion debt. Proc Natl Acad Sci USA 108:203-207. https://doi.org/10.1073/pnas.1011728108

Federal State Statistics Service (2015) Regiony Rossii. Osnovnye kharakteristiki subektov Rossiiskoi Federacii [Regions of Russia. Main characteristics of subjects of the Russian Federation]. Rosstat, Moscow

Fomina OV, Tokhtar VK (2012) Analiz adventivnoj frakcii antropogenno transformirovannyh flor $\mathrm{v}$ urbanizirovannoj srede yuga Srednerusskoj vozvyshennosti [Analysis of the alien fraction of anthropogenically transformed floras in urbanized environment in the south of central Russian upland]. Nauchnye vedomosti Belgorodskogo gosudarstvennogo universiteta, Estestvennye Nauki 18:66-73

Genovesi P, Carboneras C, Vilà M, Walton P (2015) EU adopts innovative legislation on invasive species: a step towards a global response to biological invasions? Biol Invas 17:1307-1311. https://doi.org/10.1007/s10530-014-0817-

Grigorevskaya AYa, Starodubtseva EA, Khlyzova NYu, Agafonov VA (2004) Adventivnaya flora Voronezhskoi oblasti: istoricheskii, biogeograficheskii, ekologicheskii aspekty [Historical, biogeographical, and ecological aspects of adventive flora of Voronezh Oblast]. Voronezhskii Gosudarstvennyi Universitet, Voronezh

Hijmans RJ, Cameron SE, Parra JL, Jones PG, Jarvis A (2005) Very high resolution interpolated climate surfaces for global land areas. Int J Climatol 25:1965-1978

Holub J, Jirásek V (1967) Zur Vereinheitlichung der Terminologie in der Phytogeographie. Folia Geobot Phytotax 2:69-113

Hulme PE, Pyšek P, Nentwig W, Vilà M (2009) Will threat of biological invasions unite the European Union? Science 324:40-41. https://doi.org/10.1126/science.1171111

Ibisch PL, Hoffmann MT, Kreft S, Pe'er G, Kati V, BiberFreudenberger L, DellaSala DA, Vale MM, Hobson PR, Selva N (2017) A global map of roadless areas and their conservation status. Science 354:1423-1427. https://doi. org/10.1126/science.aaf7166

Inderjit PJ, van Kleunen M, Hejda M, Babu CR, Majumdar S, Singh P, Singh SP, Salamma S, Rao BRP, Pyšek P (2018) Naturalized alien flora of the Indian states: biogeographic patterns, taxonomic structure and drivers of species richness. Biol Invas. https://doi.org/10.1007/s10530-0171622-y

Jiang H, Fan Q, Li J-T, Shi S, Li S-P, Liao W-B, Shu W-S (2011) Naturalization of alien plants in China. Biodivers Conserv 20:1545-1556. https://doi.org/10.1007/s10531-011-0044$x$

Khorun LV, Kazakova MV, Volosnova LF (2012) Floristic composition and naturalization of adventive species in flora of Ryazan oblast. In: Proceedings of the IV international scientific conference "problems in study of adventive and synanthropic floras in Russia and neighboring countries, Moscow, pp 212-215

Kowarik I, Pyšek P (2012) The first steps towards unifying concepts in invasion ecology were made one hundred years ago: revisiting the work of the Swiss botanist Albert Thellung. Divers Distrib 18:1243-1252. https://doi.org/10. 1111/ddi.12009

Krylov AV, Reshetnikova NM (2009) Adventive component of flora of Kaluga oblast: species naturalization. Bot Zhurn 94:1126-1148

Kumschick S, Bacher S, Evans T, Marková Z, Pergl J, Pyšek P, Vaes-Petignat $S$, van der Veer $G$, Vilà $M$, Nentwig W (2015) Comparing impacts of alien plants and animals using a standard scoring system. J Appl Ecol 52:552-561. https://doi.org/10.1111/1365-2664.12427

Lambdon PW, Pyšek P, Basnou C, Hejda M, Arianoutsou M, Essl F, Jarošík V, Pergl J, Winter M, Anastasiu P, Andriopoulos P, Bazos I, Brundu G, Celesti-Grapow L, Chassot P, Delipetrou P, Josefsson M, Kark S, Klotz S, Kokkoris Y, Kühn I, Marchante H, Perglová I, Pino J, Vilà M, Zikos A, Roy D, Hulme PE (2008) Alien flora of Europe: species diversity, temporal trends, geographical patterns and research needs. Preslia 80:101-149

Latombe G, Pyšek P, Jeschke JM, Blackburn TM, Bacher S, Capinha C, Costello MJ, Fernandez M, Gregory RD, Hobern D, Hui C, Jetz W, Kumschick S, McGrannachan C, Pergl J, Roy HE, Scalera R, Squires ZE, Wilson JRU, Winter M, Genovesi P, McGeoch MA (2017) A vision for global monitoring of biological invasions. Biol Conserv. https://doi.org/10.1016/j.biocon.2016.06.013

Liu J, Dong M, Miao SL, Li ZY, Song MH, Wang RQ (2006) Invasive alien plants in China: role of clonality and geographical origin. Biol Invas 8:1461-1470. https://doi.org/ 10.1007/s10530-005-5838-x

Lysenko DS (2010) Adventive plants. Flora and vegetation of Magadan region (Checklist of vascular plants and outline of vegetation). IPBN FEB RAS, Magadan, pp 235-289

Maurel N, Hanspach J, Kühn I, Pyšek P, van Kleunen M (2016) Introduction bias affects relationships between the characteristics of ornamental alien plants and their naturalization success. Glob Ecol Biogeogr 25:1500-1509. https:// doi.org/10.1111/geb.12520

Mayorov SR, Bochkin VD, Nasimovich YuA, Shcherbakov VV (2012) Adventivnaya flora Moskvy i Moskovskoi oblasti [Adventive Flora of Moscow and Moscow Oblast]. KMK, Moscow

Medvecká J, Kliment J, Májeková J, Halada L', Zaliberová M, Gojdičová E, Feráková V, Jarolímek I (2012) Inventory of the alien flora of Slovakia. Preslia 84:257-310 
Morozova OV, Starodubtseva EA, Tsarevskaya NG (2008) Adventive flora of European Russia: inventory results. Proc Russ Acad Sci, Ser Geogr 5:85-94

Notov AA, Vinogradova YuK, Mayorov SR (2011) On the problem of development and management of regional black books. Rus J Biol Invas 2:35-45. https://doi.org/10. 1134/S2075111711010061

Panasenko NN (2013) The data for the Black book of flora of Bryansk oblast. In: Transactions of the XIII congress of the Russian Botanical Society "Modern Botanical Science in Russia" and Conference "Scientific Principles of Protection and Rational Use of Vegetation Cover of Volga River Basin," Tolyatti, September 16-22, 2013. Kassandra, Tolyatti, vol 2, pp 56-58

Pergl J, Genovesi P, Pyšek P (2016a) Better management of alien species. Nature 531:173. https://doi.org/10.1038/ $531173 \mathrm{~d}$

Pergl J, Sádlo J, Petrusek A, Laštůvka Z, Musil J, Perglová I, Šanda R, Šefrová H, Šíma J, Vohralík V, Pyšek P (2016b) Black, Grey and Watch Lists of alien species in the Czech Republic based on environmental impacts and management strategy. NeoBiota 28:1-37. https://doi.org/10.3897/ neobiota.28.4824

Pyšek P (1997) Compositae as invaders—better than the others? Preslia 69:9-22

Pyšek P (1998) Is there a taxonomic pattern to plant invasions? Oikos 82:282-294. https://doi.org/10.2307/3546968

Pyšek P, Sádlo J, Mandák B (2002) Catalogue of alien plants of the Czech Republic. Preslia 74:97-186

Pyšek P, Richardson DM, Rejmánek M, Webster G, Williamson M, Kirschner J (2004) Alien plants in checklists and floras: towards better communication between taxonomists and ecologists. Taxon 53:131-143. https://doi.org/10.2307/ 4135498

Pyšek P, Richardson DM, Pergl J, Jarošík V, Sixtová Z, Weber E (2008) Geographical and taxonomic biases in invasion ecology. Trends Ecol Evol 23:237-244. https://doi.org/10. 1016/j.tree.2008.02.002

Pyšek P, Jarošík V, Hulme PE, Kühn I, Wild J, Arianoutsou M, Bacher S, Chiron F, Didžiulis V, Essl F, Genovesi P, Gherardi F, Hejda M, Kark S, Lambdon PW, DesprezLoustau A-M, Nentwig W, Pergl J, Poboljšaj K, Rabitsch W, Roques A, Roy DB, Shirley S, Solarz W, Vilà M, Winter M (2010) Disentangling the role of environmental and human pressures on biological invasions across Europe. Proc Natl Acad Sci USA 107:12157-12162. https:// doi.org/10.1073/pnas.1002314107

Pyšek P, Danihelka J, Sádlo J, Chrtek J Jr, Chytrý M, Jarošík V, Kaplan Z, Krahulec F, Moravcová L, Pergl J, Štajerová K, Tichý L (2012) Catalogue of alien plants of the Czech Republic (2nd edition): checklist update, taxonomic diversity and invasion patterns. Preslia 84:155-255

Pyšek P, Manceur AM, Alba C, McGregor KF, Pergl J, Štajerová K, Chytrý M, Danihelka J, Kartesz J, Klimešová J, Lučanová M, Moravcová L, Nishino M, Sádlo J, Suda J, Tichý L, Kühn I (2015) Naturalization of central European plants in North America: species traits, habitats, propagule pressure, residence time. Ecology 96:762-774. https://doi. org/10.1890/14-1005.1

Pyšek P, Pergl J, Essl F, Lenzner B, Dawson W, Kreft H, Weigelt P, Winter M, Kartesz J, Nishino M, Antonova LA,
Barcelona JF, Cabezas FJ, Cárdenas D, Cárdenas-Toro J, Castaño N, Chacón E, Chatelain C, Dullinger S, Ebel AL, Figueiredo E, Fuentes N, Genovesi P, Groom QJ, Henderson L, Inderjit Kupriyanov A, Masciadri S, Maurel N, Meerman J, Morozova O, Moser D, Nickrent D, Nowak PM, Pagad S, Patzelt A, Pelser PB, Schulze M, Seebens H, Shu W, Thomas J, Velayos M, Weber E, Wieringa JJ, Baptiste MP, van Kleunen M (2017) Naturalized and invasive flora of the world: species diversity, taxonomic and phylogenetic patterns, geographic distribution and global hotspots of plant invasion. Preslia 89:203-274. https://doi.org/10.23855/preslia.2017.203

Pyšek P, Meyerson LA, Simberloff D (2018) Introducing “Alien Floras and Faunas", a new series in Biological Invasions. Biol Invasions. https://doi.org/10.1007/s10530-017-16481

R Development Core Team (2017) R: a language and environment for statistical computing. R Foundation for Statistical Computing, Vienna

Razanajatovo M, Maurel N, Dawson W, Essl F, Kreft H, Pergl J, Pyšek P, Weigelt P, Winter M, van Kleunen M (2016) Plants capable of selfing are more likely to become naturalized. Nat Commun 7:13313. https://doi.org/10.1038/ ncomms13313

Řehák J, Řeháková B (1986) Analýza kategorizovaných dat v sociologii [Analysis of categorized data in sociology]. Academia, Prague

Richardson DM, Pyšek P, Rejmánek M, Barbour MG, Panetta FD, West CJ (2000) Naturalization and invasion of alien plants: concepts and definitions. Divers Distrib 6:93-107. https://doi.org/10.1046/j.1472-4642.2000.00083.x

Rumlerová Z, Vilà M, Pergl J, Nentwig W, Pyšek P (2016) Scoring environmental and socioeconomic impacts of alien plants invasive in Europe. Biol Invas 18:3697-3711. https://doi.org/10.1007/s10530-016-1259-2

Rzhevuskaya NA (2012) The data to the "Black book" of flora of Lipetsk oblast. In: Proceedings of the IV international scientific conference "Problems in study of adventive and synanthropic floras in Russia and neighboring countries, Moscow, pp 172-173

Schroeder F-G (1969) Zur Klassifizierung der Anthropochoren. Vegetatio 16:225-238

Seebens H, Essl F, Dawson W, Fuentes N, Moser D, Pergl J, Pyšek P, van Kleunen M, Weber E, Winter M, Blasius B (2015) Global trade will accelerate plant invasions in emerging economies under climate change. Glob Change Biol 21:4128-4140. https://doi.org/10.1111/gcb.13021

Seebens H, Blackburn TM, Dyer EE, Genovesi P, Hulme PE, Jeschke JM, Pagad S, Pyšek P, Winter M, Arianoutsou M, Bacher S, Blasius B, Brundu G, Capinha C, Celesti-Grapow L, Dawson W, Dullinger S, Fuentes N, Jäger H, Kartesz J, Kenis M, Kreft H, Kühn I, Lenzner B, Liebhold A, Mosena A, Moser D, Nishino M, Pearman D, Pergl J, Rabitsch W, Rojas-Sandoval J, Roques A, Rorke S, Rossinelli S, Roy HE, Scalera R, Schindler S, Štajerová K, Tokarska-Guzik B, van Kleunen M, Walker K, Weigelt P, Yamanaka T, Essl F (2017) No saturation in the accumulation of alien species worldwide. Nat Commun 8:14435. https://doi.org/10.1038/ncomms 14435

Shrestha BB (2016) Invasive alien plant species in Nepal. In: Jha PK, Siwakoti M, Rajbhandary S (eds) Frontiers in Botany. 
Central Department of Botany, Tribhuvan University, Kirtipur, Kathmandu, pp 269-284

Silaeva TB, Ageeva AM (2016) Alien species in flora of the Moksha River basin. Russ J Biol Invas 7:182-188. https:// doi.org/10.1134/S2075111716020120

Steinberg G, Colla P (1995) CART: Tree-structured nonparametric data analysis. Salford Systems, San Diego

Thellung A (1912) La flore adventice de Montpellier. Memoires de la Sociéte Nationale des Sciences Naturelles et Mathematiques de Cherbourg 38:57-728

Tremasova NA, Borisova MA, Borisova EA (2012) Invasive species of plants of the Yaroslavl region. Yarosl Ped Vestn 3:103-111

Uludag A, Aksoy N, Yazlık A, Arslan ZF, Yazmış E, Üremis I, Cossu TA, Groom Q, Pergl J, Pyšek P, Brundu G (2017) Alien flora of Turkey: checklist, taxonomic composition and ecological attributes. NeoBiota 35:61-85. https://doi. org/10.3897/neobiota.35.12460

van Kleunen M, Dawson W, Essl F, Pergl J, Winter M, Weber E, Kreft H, Weigelt P, Kartesz J, Nishino M, Antonova LA, Barcelona JF, Cabezas FJ, Cárdenas D, Cárdenas-Toro J, Castaño N, Chacón E, Chatelain C, Ebel AL, Figueiredo E, Fuentes N, Groom QJ, Henderson L, Inderjit Kupriyanov A, Masciadri S, Meerman J, Morozova O, Moser D, Nickrent DL, Patzelt A, Pelser PB, Baptiste MP, Poopath M, Schulze M, Seebens H, Shu W, Thomas J, Velayos M, Wieringa JJ, Pyšek P (2015) Global exchange and accumulation of non-native plants. Nature 525:100-103. https://doi.org/10.1038/nature14910

Vilà M, Basnou C, Pyšek P, Josefsson M, Genovesi P, Gollasch S, Nentwig W, Olenin S, Roques A, Roy D, Hulme PE, DAISIE Partners (2010) How well do we understand the impacts of alien species on ecological services? A panEuropean cross-taxa assessment. Front Ecol Environ 8:135-144. https://doi.org/10.1890/080083

Vilà M, Rohr RP, Espinar JL, Hulme PE, Pergl J, Le Roux J, Schaffner U, Pyšek P (2015) Explaining the variation in impacts of non-native plants on local-scale species richness: the role of phylogenetic relatedness. Glob Ecol Biogeogr 24:139-146. https://doi.org/10.1111/geb.12249

Vinogradova YuK, Kuprianov AN (eds) (2016) Chernaya kniga flory Sibiri. Russian Academy of Sciences, Novosibirsk

Vinogradova YuK, Mayorov SR, Khorun LV (2010) Chernaya kniga flory Srednei Rossii: chuzherodnye vidy rastenii v ekosistemakh Srednei Rossii [The Black Book of flora of Central Russia: alien plant species in ecosystems of Central Russia]. GEOS, Moscow

Vinogradova YuK, Mayorov SR, Notov AA (2011) Chernaya kniga flory Tverskoi oblasti: chuzherodnye vidy rastenii $\mathrm{v}$ ekosistemakh Tverskogo regiona [The Black Book of flora of Tver area: alien plant species in ecosystems of the Tver Region]. KMK, Moscow

Wu S-H, Sun H-T, Teng Y-C, Rejmánek M, Chaw S-M, Aleck Yang T-Y, Hsieh C-F (2010) Patterns of plant invasions in China: taxonomic, biogeographic, climatic approaches and anthropogenic effects. Biol Invas 12:2179-2206. https:// doi.org/10.1007/s10530-009-9620-3

Xu H, Qiang S, Genovesi P, Ding H, Wu J, Meng L, Han Z, Miao J, Hu B, Guo J, Sun H, Huang C, Lei J, Le Z, Zhang $\mathrm{X}$, He S, Wu Y, Zheng Z, Chen L, Jarošík V, Pyšek P (2012) An inventory of invasive alien species in China. NeoBiota 15:1-26. https://doi.org/10.3897/neobiota.15. 3575 